
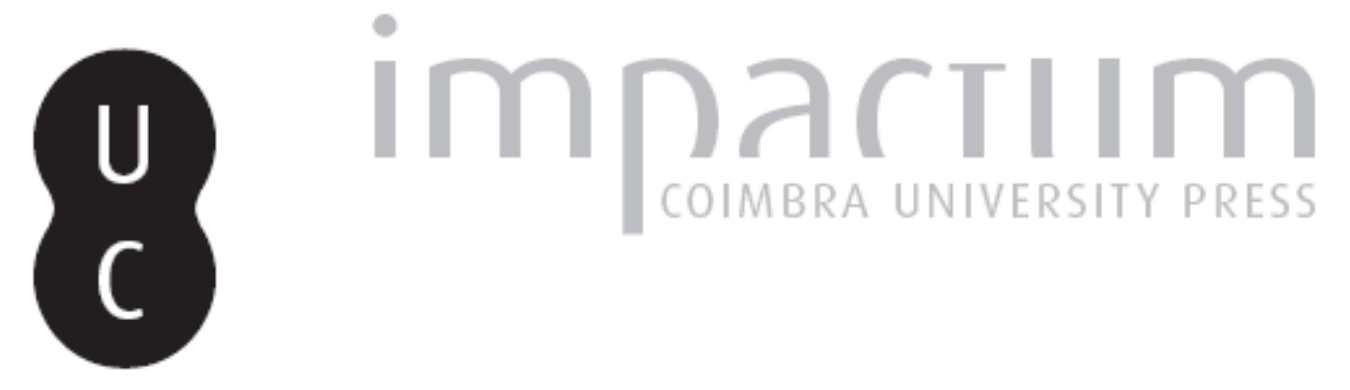

\title{
Reuse of the existing: teaching and theoretical investigations
}

Autor(es): $\quad$ Giovannelli, Anna

Publicado por: Editorial do Departamento de Arquitetura

URL persistente:

URI:http://hdl.handle.net/10316.2/45186

DOI:

DOl:https://doi.org/10.14195/1647-8681_9_8

Accessed : $\quad$ 26-Apr-2023 14:24:24

A navegação consulta e descarregamento dos títulos inseridos nas Bibliotecas Digitais UC Digitalis, UC Pombalina e UC Impactum, pressupõem a aceitação plena e sem reservas dos Termos e Condições de Uso destas Bibliotecas Digitais, disponíveis em https://digitalis.uc.pt/pt-pt/termos.

Conforme exposto nos referidos Termos e Condições de Uso, o descarregamento de títulos de acesso restrito requer uma licença válida de autorização devendo o utilizador aceder ao(s) documento(s) a partir de um endereço de IP da instituição detentora da supramencionada licença.

Ao utilizador é apenas permitido o descarregamento para uso pessoal, pelo que o emprego do(s) título(s) descarregado(s) para outro fim, designadamente comercial, carece de autorização do respetivo autor ou editor da obra.

Na medida em que todas as obras da UC Digitalis se encontram protegidas pelo Código do Direito de Autor e Direitos Conexos e demais legislação aplicável, toda a cópia, parcial ou total, deste documento, nos casos em que é legalmente admitida, deverá conter ou fazer-se acompanhar por este aviso.

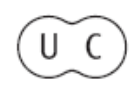



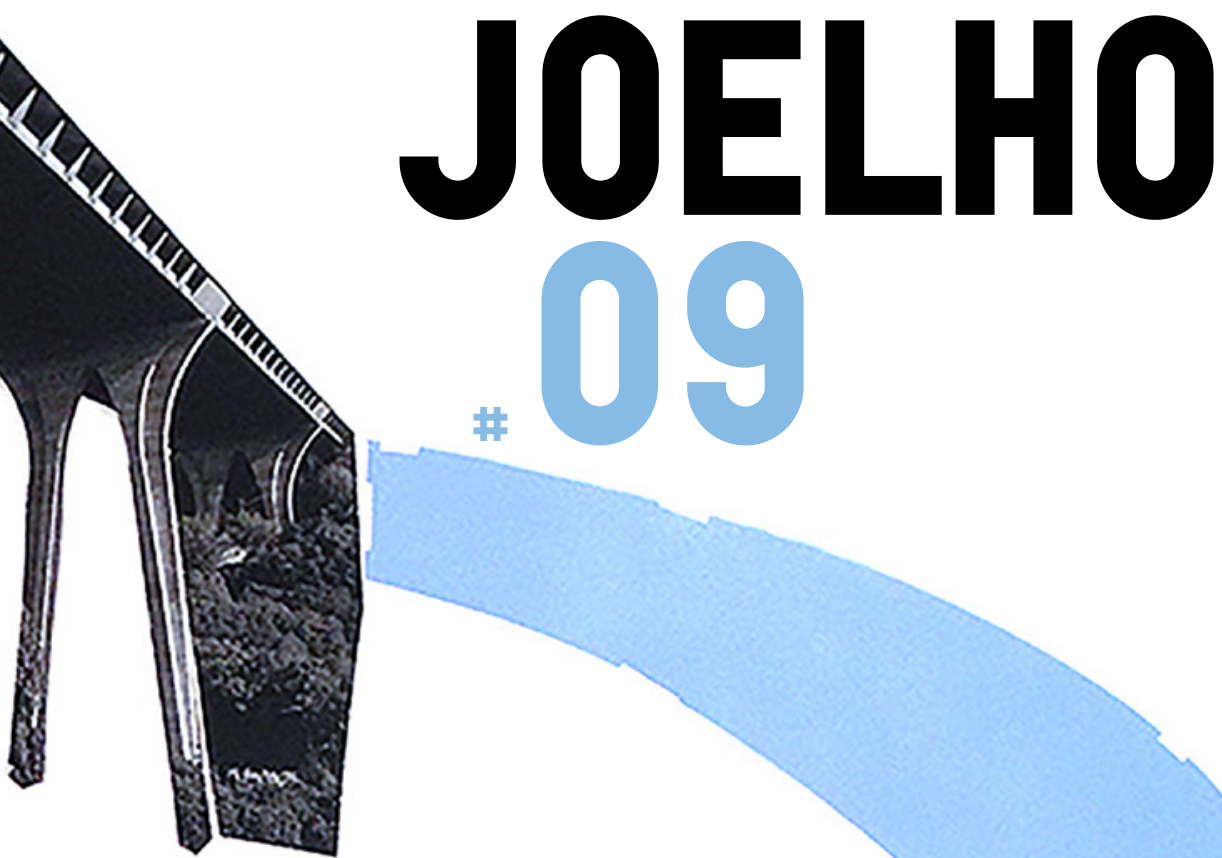

\section{REUSE OF MODERNIST BUILDINGS: PEDAGOGY AND PROFESSION}

Guest Editors:

Michel Melenhorst

Paulo Providência

Gonçalo Canto Moniz

ZUS: Elma van Boxel

and Kristian Koreman

Atelier do Corvo

Tilemachos Andrianopoulos

Albena Yaneva

Carlos Fortuna

Christian Gänshirt

Dieter Leyssen

Carolina Coelho

Anna Giovannelli

António Carvalho

Marta Peixoto

Els De Vos

and Eva Storgaard

Exhibition

$2^{\text {nd }}$ RMB Workshop, Coimbra

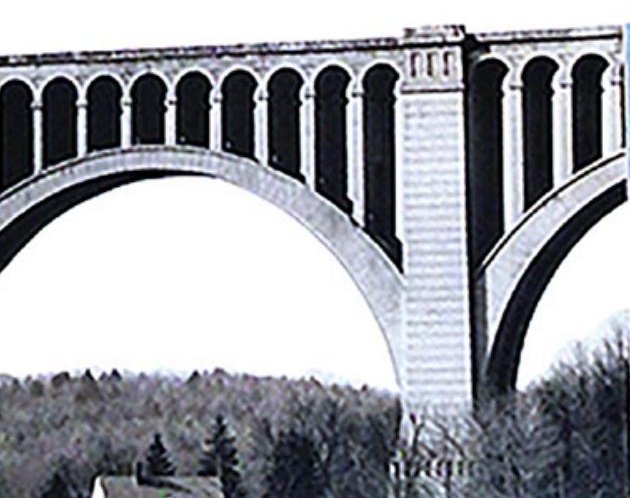


Reuse of the existing: teaching and theoretical investigations

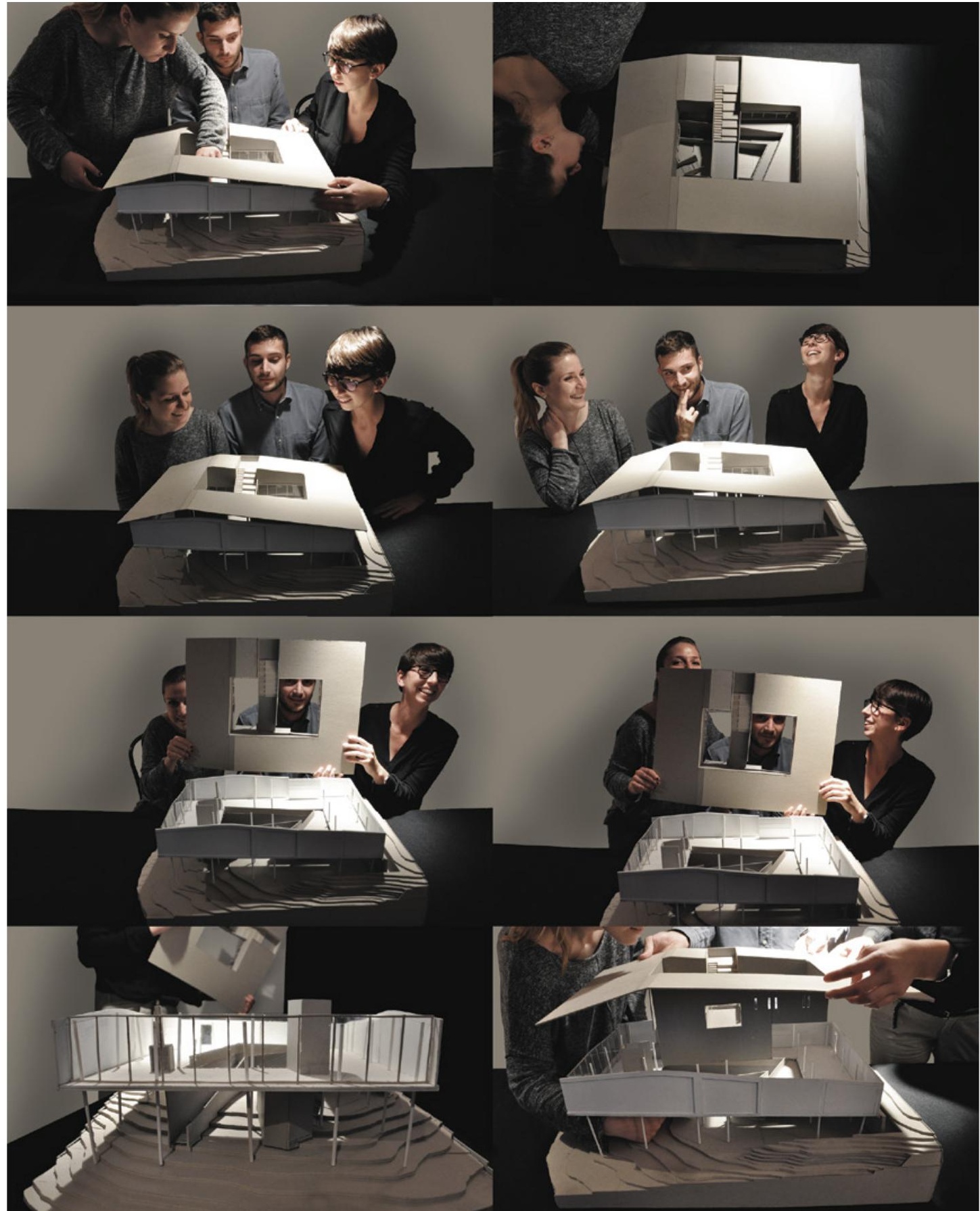




\section{Introduction}

Design the contemporary city and architecture means, first of all, dealing with the existing, a huge amount of abandoned space, of uninhabited factories, of crumbling artefacts, of an entire territory which asks to be taken care of. After years of urban sprawl with soil consumption, it is necessary to rethink the way of planning in the existing contexts of the contemporary city and its environmental sustainability. The immediacy of new constructions is often preferred to the recycling of existing ones that work in the long term and return value to the places and their historical stratifications. This is why today the reuse of the existing represents the real emergency to face with a process of regeneration of cities and their territories, where the architectural project, with the contribution of other disciplines - such as archaeology and restoration, geography and landscape design - represents the only instrument able to offer an answer to the current problems of urban structures. Reuse is actually a necessity as well as an emergency; reuse is the ontological condition of architecture because every building has always recycled materials and spaces to reshape the new and we need to analyse past examples of reuse in order to create a methodology for the design reuse of existing structures. This paper aims to contribute to the definition of a teaching methodology of reuse through design and proposes an approach that interprets those characters of the different architectural forms of the existing modernist buildings.

\section{Reuse in the past}

The history of architecture provides us with many striking examples of how, before a new building is begun, the existing 'raw material' on the site has been taken into consideration. There are many examples: from the typological reuse of the basic building of historical urban structures through the evolutionary process, to the ancient reuse, that have converted the existing buildings by constructing the new forms above or around architecture: temples becomes cathedrals, monasteries become prisons and then again museums; these are some types of reuse that have produced famous examples of contamination between the old and the new layers, as the Palazzo Savelli ${ }^{1}$ that is the reuse of the ancient Teatro di Marcello in Rome, by Baldassarre Peruzzi.

The Baroque structure of the Cathedral of Siracusa has an eclectic relationship with the existent temple of Athena, the Athenaion, in which the new outside shell of the church envelops the ancient building in a remarkable overlapping which leaves its Doric columns partially visible, so that they are re-contextualised into a new sacred order. ${ }^{2}$

Another outstanding example of reuse is Leon Battista Alberti's design for the Tempio Malatestiano in Rimini, where the new enveloping structure, based on the rules of classicism, encloses the existent $13^{\text {th }}$ century church and establishes a substantial divergence between the interior space and the design of the side facades. Although clearly implied in Alberti's project, the outer sides of the Tempio Malatestiano
Frontispiece "the manipulation of Casa De Vidro" (by Lina Bo Bardi): Students: A. Borreca, A. Lione, M. Dragoni by Sapienza Roma, 2016 
display a sizeable discrepancy between the continuity of the ancient building and the variations imposed by the Renaissance transformation.

In Vicenza, Palladio enclosed the medieval Palazzo della Ragione within an external supportive structure (using his famous serliana arches) so as to re-interpret one of what he calls in his Quattro Libri dell'Architettura "the Basilicas of our time"3

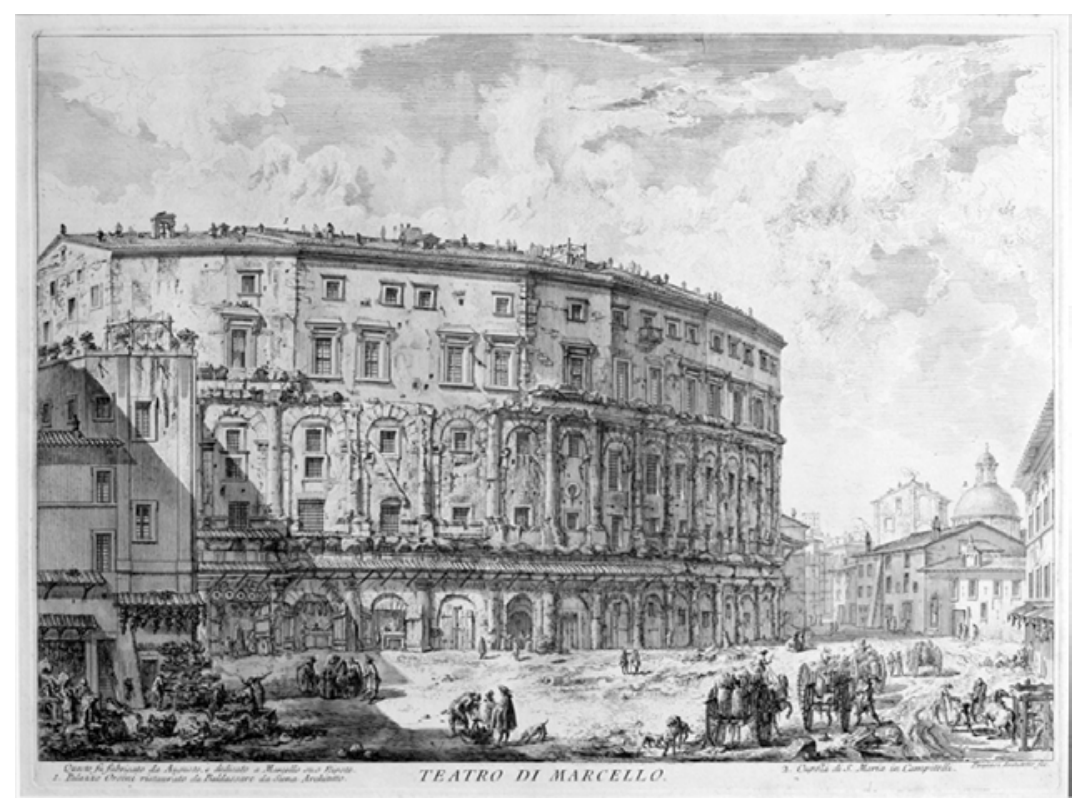

Fig. 1 Giovanni Battista Piranesi, Teatro di Marcello, Roma, 1774

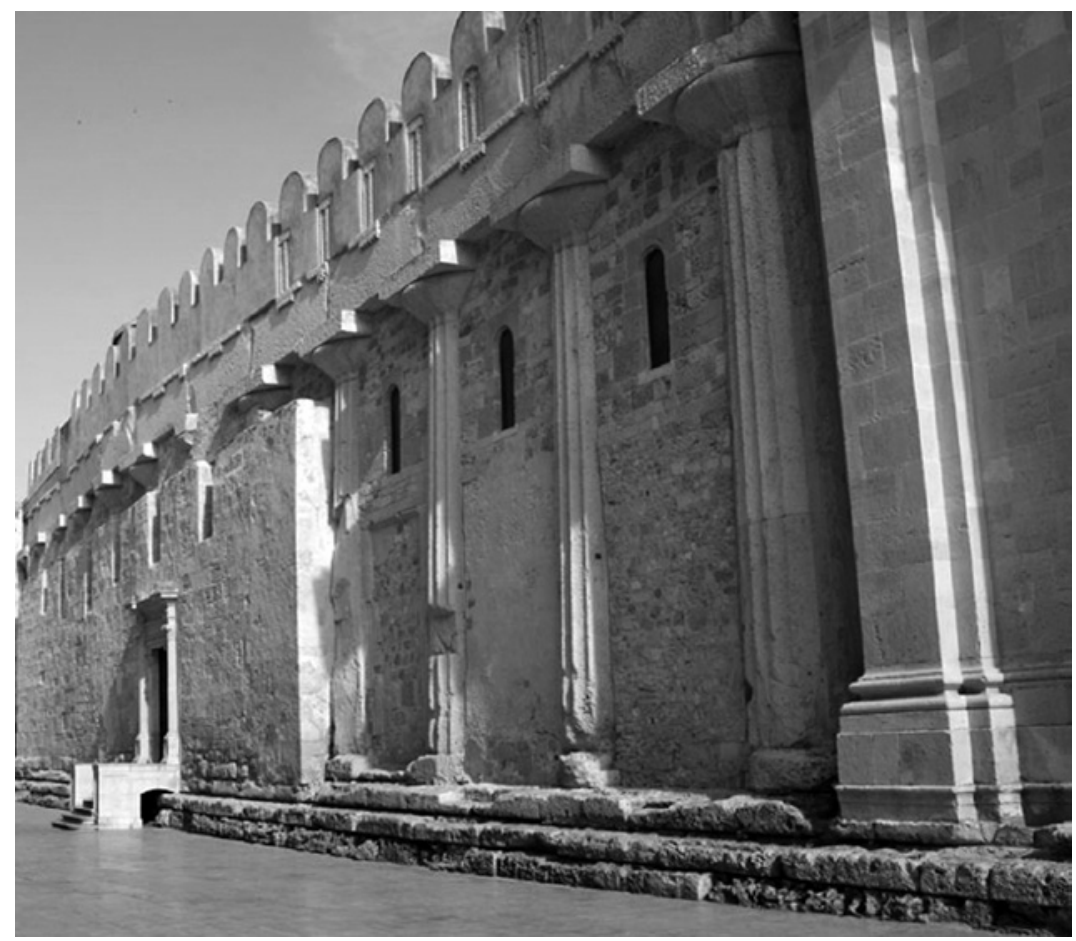

Fig. 2 The Baroque Cathedral of Siracusa, side façade, Sicily 
The original buildings then serve as the basis on which new architecture is raised as a continuation of what already exists. Reuse always happens in continuation with the past, even as it invokes the spirit of its own time, in which methods and techniques are employed that belong to the original form of the buildings. The continuation is discriminatory, however and does not impose a new ordering but re-interprets the existing in an updated form of language which is appropriate to each time period. Modernity subsequently interrupts this discriminating sense of continuity; it requires the tabula rasa of the existent and of all history, which it regards as an obstacle to new architecture. To concern oneself, therefore, with the reuse of the Modern seems like a contradiction in terms; if modern architecture implies a break with the past, how is it possible that the entire repertoire of modernity is now the field of research for reuse projects? The idea of modernity as a shared architectural and cultural heritage, allows us to make an informed assessment of the concept of reuse, not as restoration, but as refurbishment or architectural renovation; in other words, those design interventions aimed at re-appropriating the forms of the existing architecture, be it industrial, modernist, or whatever, re-evaluating its original features and re-creating them in the context of a modern city. Yet what are the conditions needed if we are to set in motion the reuse of such a vast number of buildings? Is reuse merely the 're-functionalising' of what already exists, or is it in fact the transformation of built structures which simultaneously reactivates a broader process of more extensive spatial organisms?

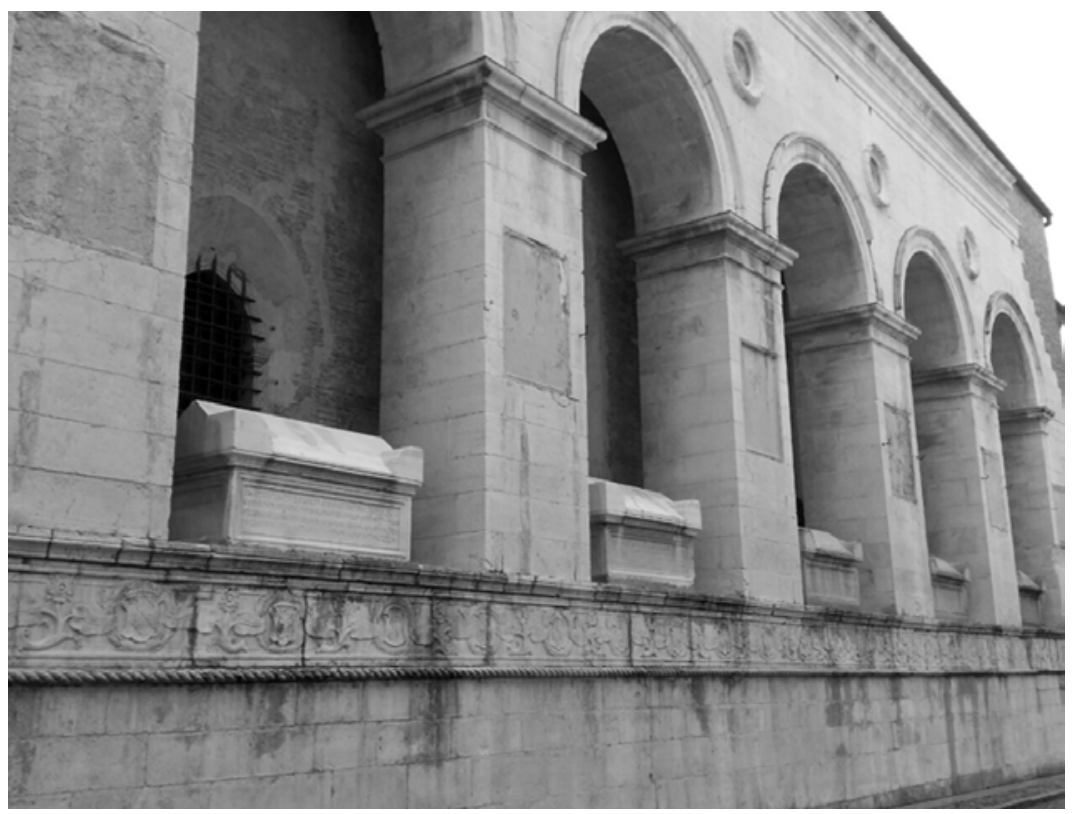

Fig. 3 Leon Battista Alberti, Tempio Malatestiano, side façade, Rimini, XV century 


\section{of architectural form}

In the absence of more effective and codified interpretative models, such as those used in the science of restoration, we need to investigate how the architectures of the past reuse material and structures in building the new, in order to create a methodology for projects involving the reuse of existing. Nowadays architectural design projects tend to focus on refurbishment, which often involves only the interior spaces of buildings, leaving the architecture itself relatively untouched. With this teaching experience we investigate the theme of the reuse of the architecture and the strategies of its transformation, both in the interior of existing buildings, and the spaces in-between surrounding them. The aim is that of identifying design techniques for intervention on the artefact assumed in its neglected condition. We want to experiment a compositional approach that operates through the process of manipulation of the form, choosing as a field of action some significant architectural texts of the twentieth century that are placed in specific contextual situations. Methodology in the design process related to the reuse of neglected buildings, both modernist and post industrial, consists of a "reading" of their architectural form, when the design actions work with additions, subtractions, manipulations of the building heritage. The existing becomes the conceptual framework of new architectural configurations generated by the necessary refurbishment of buildings.

The practical methodology of projects for the reuse of existing buildings is based on a selective examination of the structures concerned, an analysis of their original form on which to base plans for their transformation. This analysis sets up what are the basic components of its architectural form: five exempla of modernist architecture, as Casa de Vidro by Lina Bo Bardi, or Casa Butanta, by Paulo Mendes da Rocha and other important modernist buildings were analysed; in the first stage, compositional diagrams and models were created in which a critical reading of the work was made, followed by a stage where each building went through a process of 'ruination' - the form of the ruin was the form of the original structure; this allowed the students to progress to a form of compositional manipulation, the transformation project in which new configurations of the existent building were constructed.

This exercise was ostensibly theoretical and had a considerable degree of abstraction that appeared to distance it from reality, but it turned out to be an effective project technique for examining the original resistant architecture of the building and understanding how it could be transformed, in other words, its future reuse. It attempts to adopt the same approach used by architects of the past, where the existing building was not only the receptacle of new functions, but the formal structure into which the new spatial, material and formal solutions could 


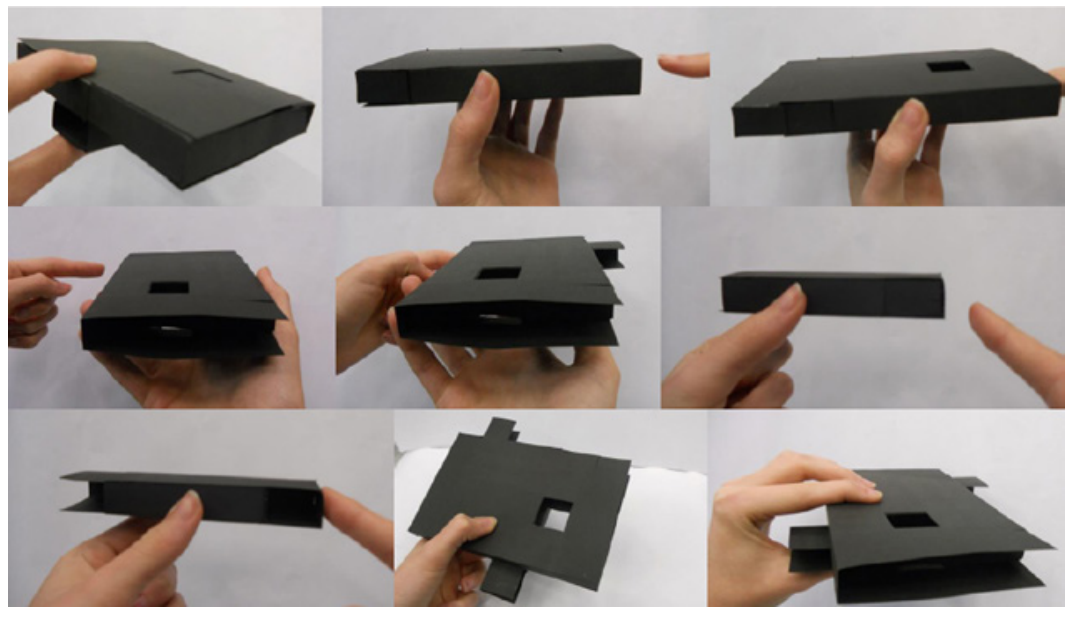

Fig. 4 Lina Bo Bardi, Casa de Vidro,

manipulation of form. Student's model, Roma, faculty of Architecture, 2016

Fig. 5a Paulo Mendes da Rocha Casa Butanta, manipulation of form. Student's comparative drawings, Roma, Faculty of Architecture, 2016

Fig. 5b Paulo Mendes da Rocha Casa Butanta, manipulation of form. Student's comparative models, Roma, Faculty of Architecture, 2016
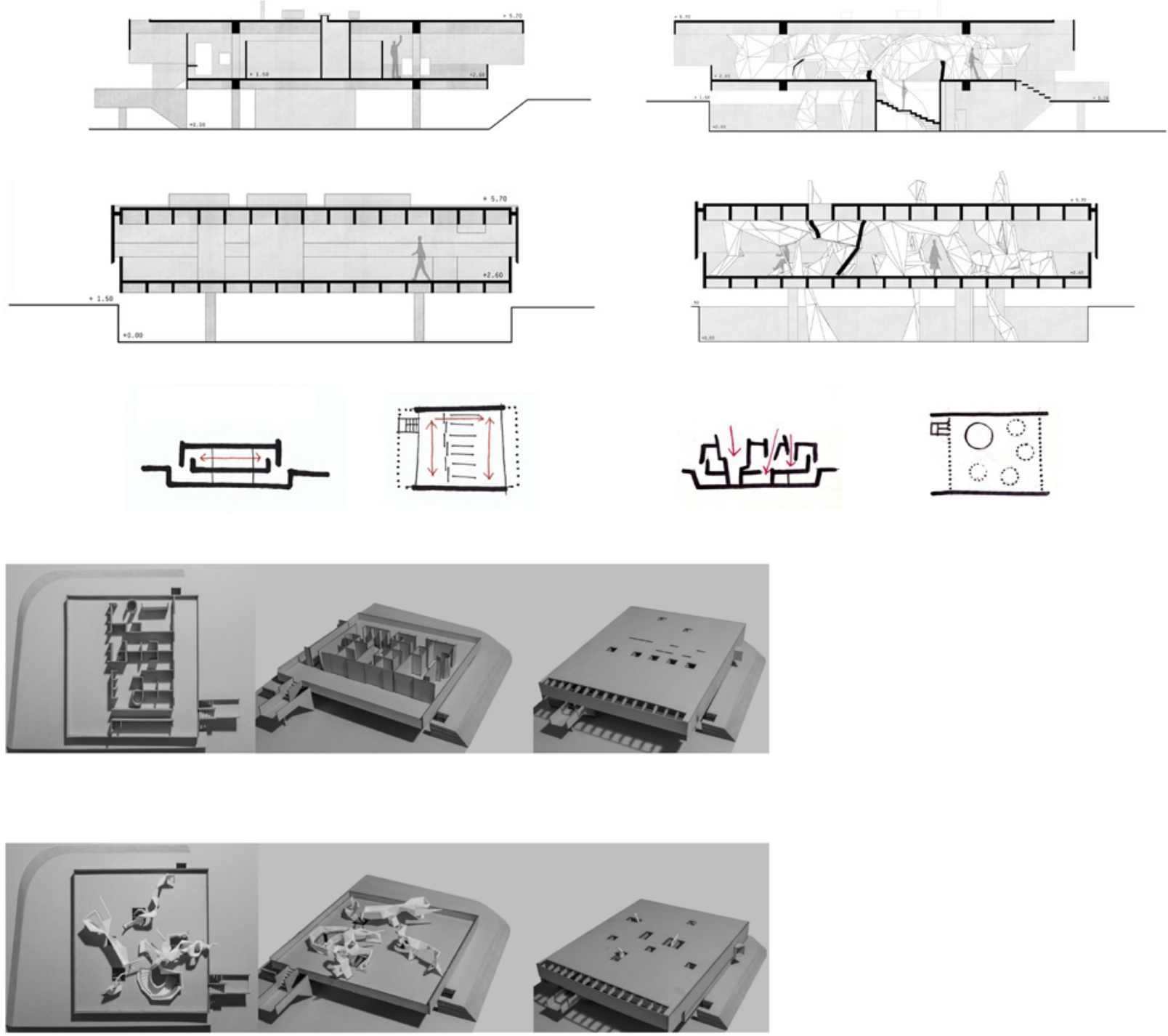

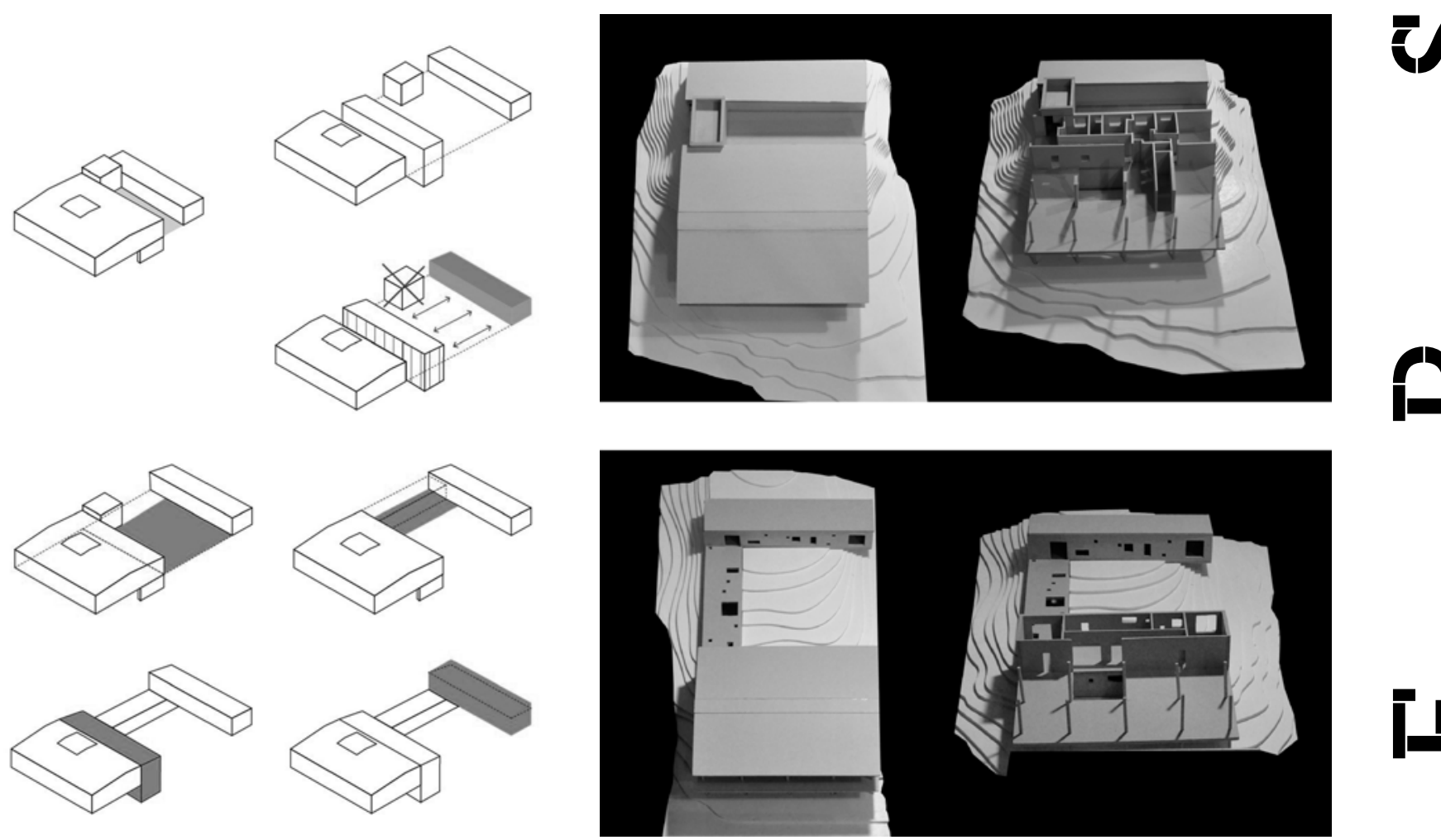

Fig. 6a Paulo Mendes da Rocha Casa Butanta, manipulation of form. Student's design process, Roma, Faculty of Architecture, 2016

Fig. 6b Lina Bo Bardi, Casa de Vidro, manipulation of form. Student's comparative models, Roma, Faculty of Architecture, 2016

be woven. At this point reuse becomes the point of interaction between two systems: one that exists, and the other that is grafted onto it to produce the complex set of elements that define the project.

\section{Images of reuse: the architecture of re-discovered spaces}

The experiments are carried out at different scales on single buildings, with architectural additions to existing buildings. All the projects operate by undertaking certain actions that elaborate the new forms of architectural reuse by reshaping some post industrial buildings, located in different places, or the abandoned structures of modernist architectures such as important public buildings from the XX century in Rome

\section{New rooms}

As Louis Kahn wrote "The room is the beginning of architecture. It is the place of the mind". The room is thus the unit of measurement of the space that is constructed in the sequencing, repetition or uniqueness of the form. In these comparative exercises, the room is the form of the original structure and the figure of its reuse; it is the difference between the form of the container and the figure of the contents, between the existent and the project.

The first exercise in reuse takes place inside the huge open space of Soundstage 1, in the "Centro Sperimentale di Cinematografia" in Cinecittà, Rome, designed in the 1930's. 


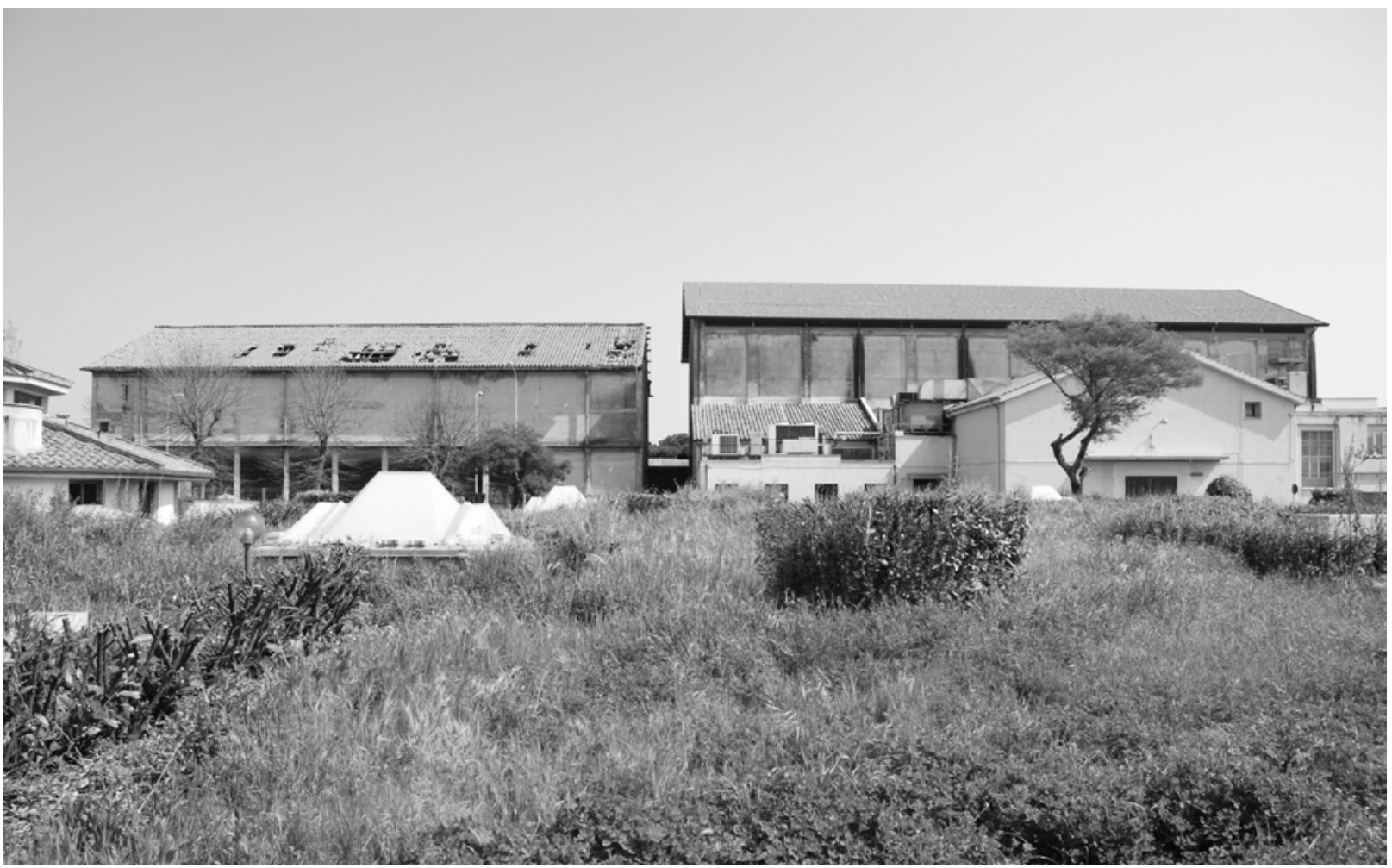

The project involves creating a National Cinema School, a cultural and educational centre dedicated to the theory and practice of the cinematographic arts. The reuse project sets out to organize a multiple functional programme, divided into various specific activities inside a very large space. On the different floors a sequence of spaces will be constructed, with new relationships between solid structures and empty spaces, and between volumes and surfaces; a special correlation will be created between a new puntiform framework and the original structure, in a continuous dialogue with the existing container.

Two of these work on the idea of an analytical space, in which the order of the new structural spans quantifies the composition of volumes and internal partitions, where the positioning of the distributive elements determines the hierarchy of the spaces. Other projects put forward the idea of a plastic space, where, in some cases, the interior is conceived of as a large solid structure to be excavated; the huge open space is invaded by a system of floors that generate fluid spaces with open overhangs and suspended volumes.

Another room is the Africa Cinema, one of the many cinemas that the engineer Riccardo Morandi has designed in Rome since the 1930s. The cinema was built in the Fifties inside an irregular modernist urban block. It is an interesting structure because this informality is grafted into the voids with three infill faced on the road. The project proposes a new urban room, because create a new relationship with the interior
Fig. 7a Centro Sperimentale di Cinematografia, the old Soundstage 1, Cinecittà, Roma 

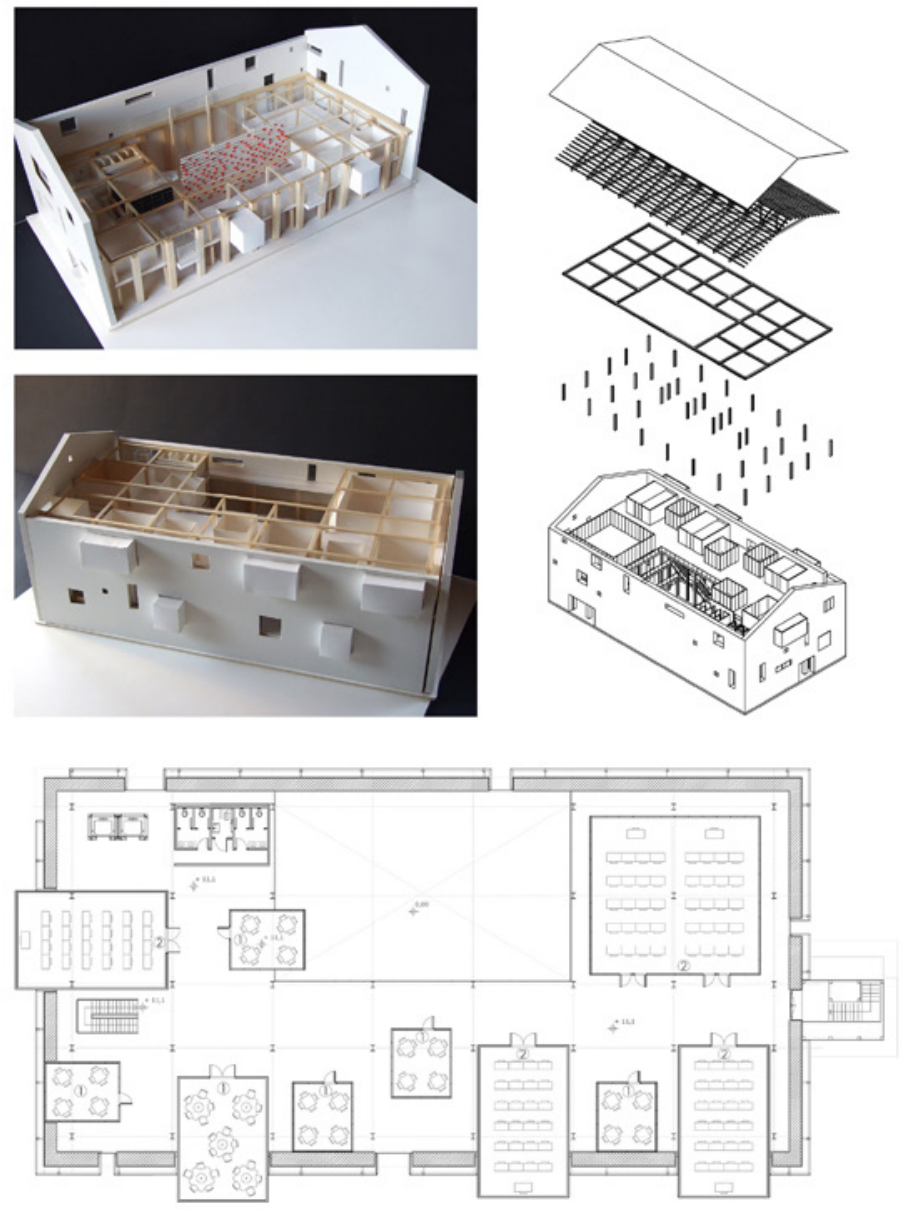

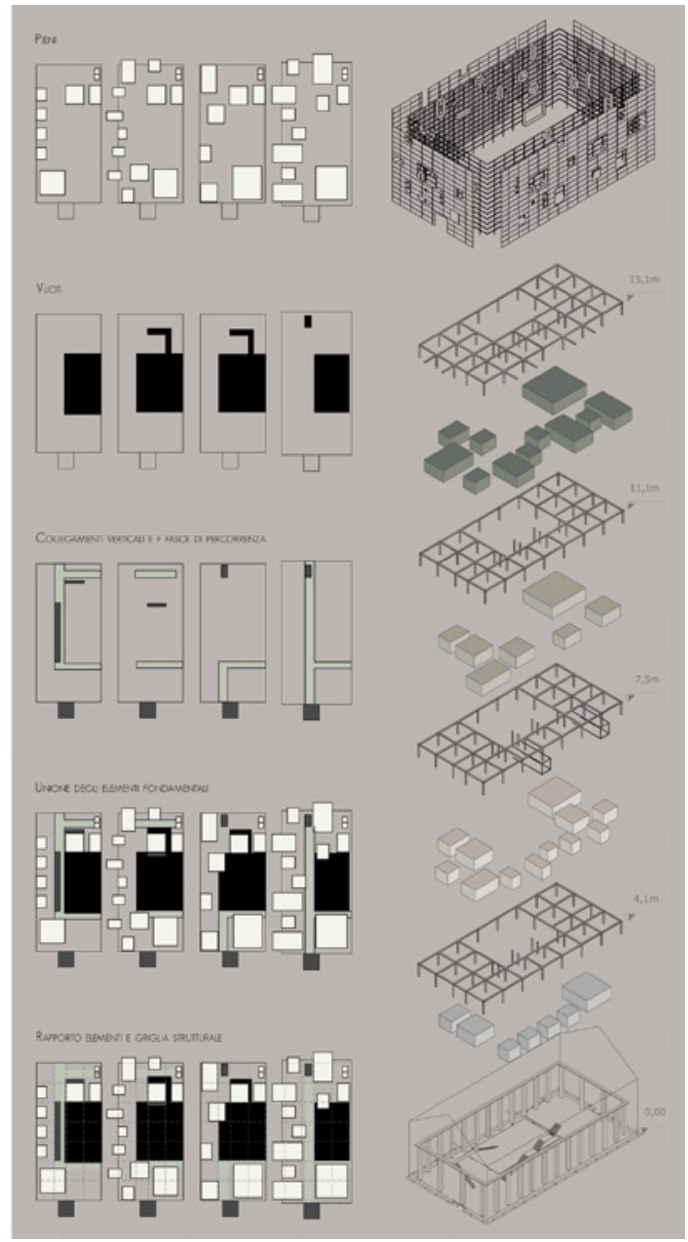

Fig. 7b The reuse of the empty space of the Soundstage 1: Ilaria Matano, degree thesis Roma, Faculty of Architecture, 2008 space of the block. The three infill become the new accesses to the public space and to the new use of the interior spaces, - Laboratories and offices - that are created with the lifting of a floor of the new hall. The new rooms are bounded by a system of structural partitions that support the new hall.

\section{Grafting _cutting for reuse}

The word 'grafting', as an implant is probably the most useful architectural term to help us appreciate the importance of an operation that rehabilitates the abandoned structure of a post-industrial building or a modern disused one. In the second life of a building there are new organised spaces that function as grafting with new perimeters in which recycled materials are assembled and abandoned artefacts are given a new lease of life. Or the regeneration takes place by removing parts of the building or by making partial dissections that remove certain parts of the structure and reveal new representational possibilities. This is what Gordon Matta Clark meant when he spoke of "creating metaphorical incisions in the space/place (...) to reuse the old, the 

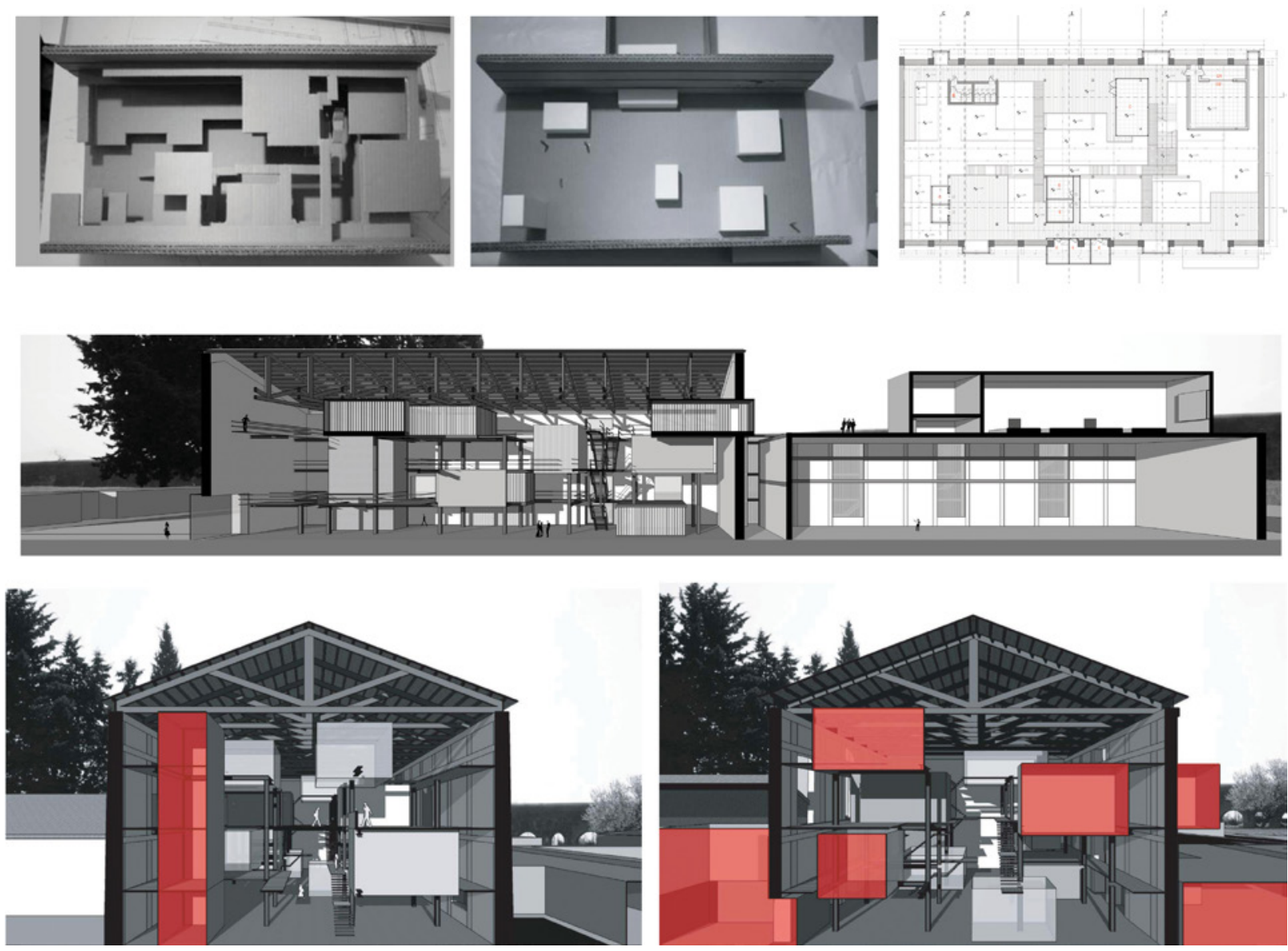

existing structure of thought, of imagination, and of understanding" ${ }^{4}$. In this sense, the project of reuse manages to graft new implants of form, which at times lie alongside the lifeless organs, and reinvigorate the space with new architectural transformations.

Factories, no longer inhabited by machinery or labour force, become the grammar of any future architectural grafting. These are often interstitial spaces, or surfaces resulting from partial demolitions or collapse of fabric, which opens up new potentials for reuse projects. The project has to pay strict attention to this in between, between the remaining fragments that are to be reused and the form of the new structure.

In Barcelona, the fragmentation and complexity of the factory Car Ricart are the focus of the project, that works with them in a layout that overlaps past and present structures. The project proposes to underline the resistance of the factory to the Plan Cerdà, virtually re-proposing the road that was superimposed to cross it, by means of a large ramp, a grafting that recreates the fragments that surround it.
Fig. 7c The reuse of the empty space of the Soundstage 1: Matteo Martini, degree thesis Polytechnic University of Milan, Faculty of Architecture, 2007 


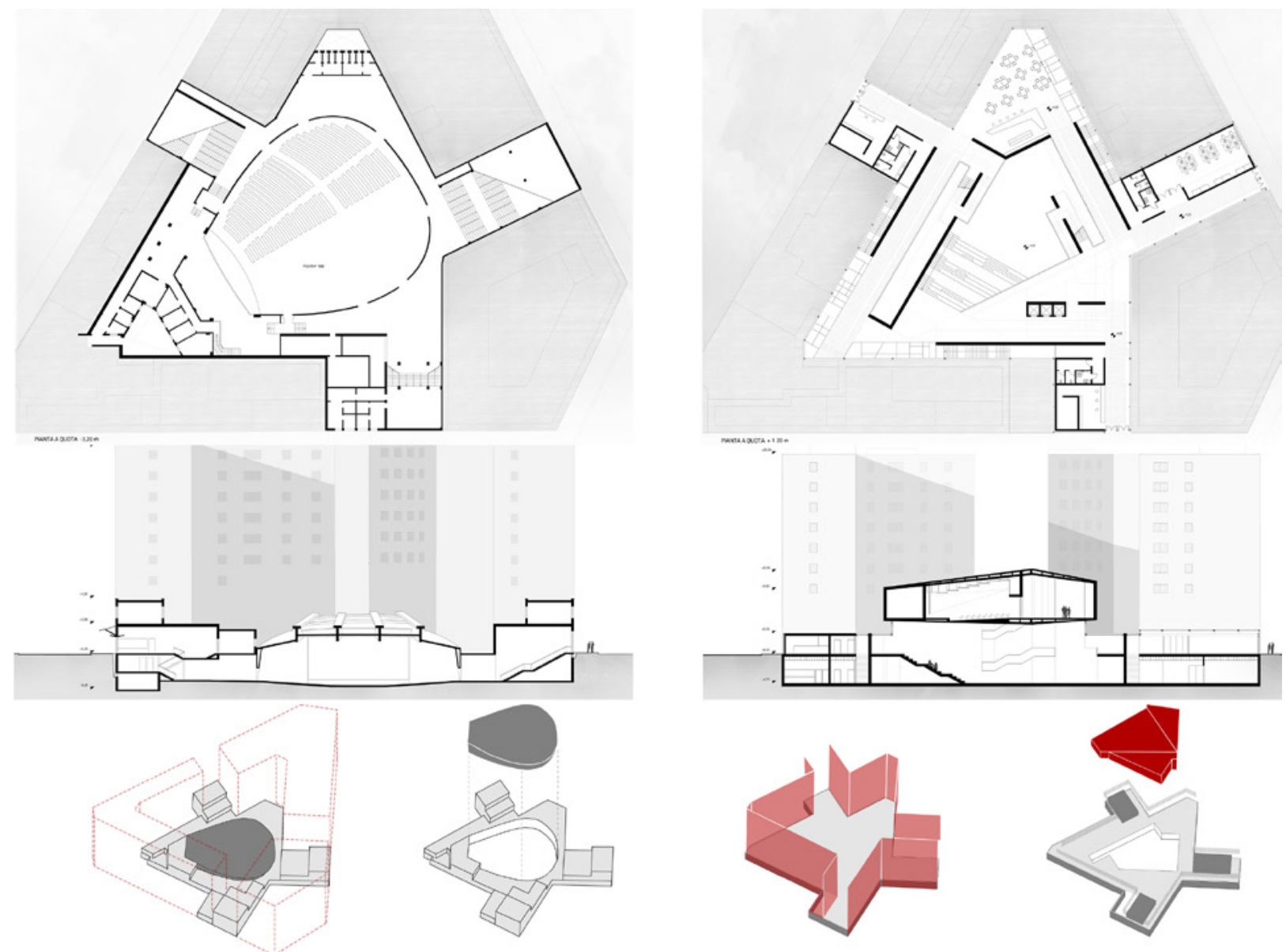

Fig. 8 The reuse of the Africa Cinema in Rom by R. Morandi: Jole Lutzu, degree thesis Roma, Faculty of Architecture, 2017

Fig. 9 Gordon Matta-Clark Conical-Intersect, 1975

Fig. 10a The reuse of the Can Ricart factory in Barcelona, Spain. Design process. Flaminia lacobini, degree thesis Roma, Faculty of Architecture, 2017

Fig. 10b The reuse of the Can Ricart factory in Barcelona, Spain. Model study. Flaminia lacobini, degree thesis Roma, Faculty of Architecture, 2017

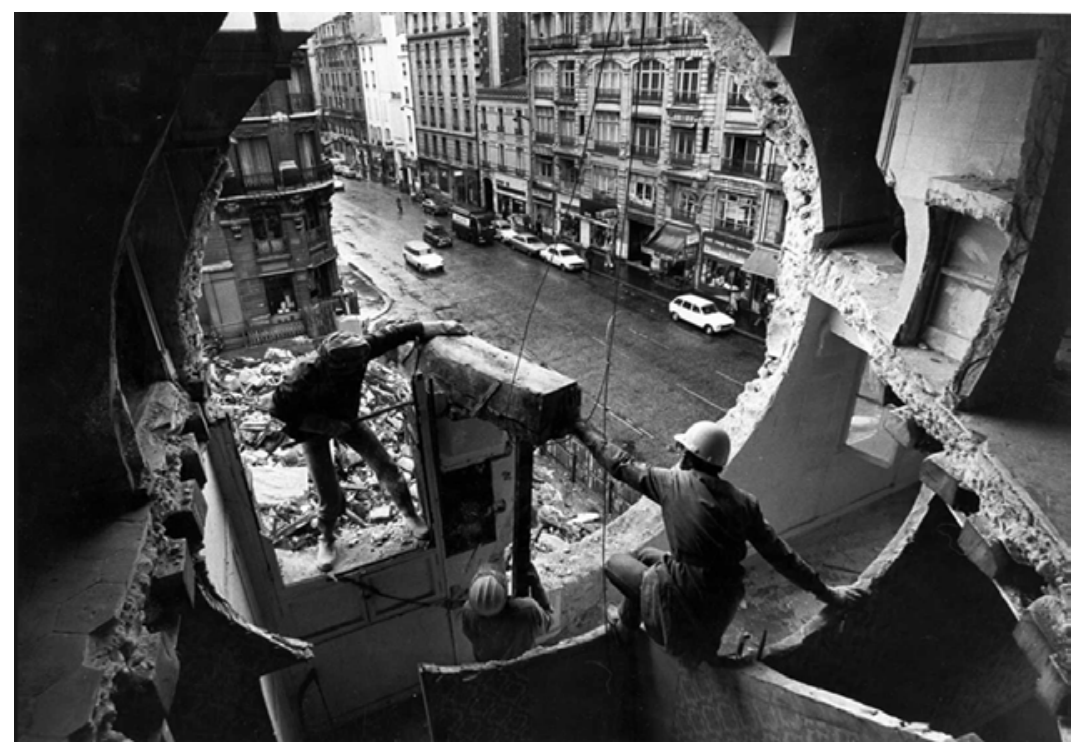



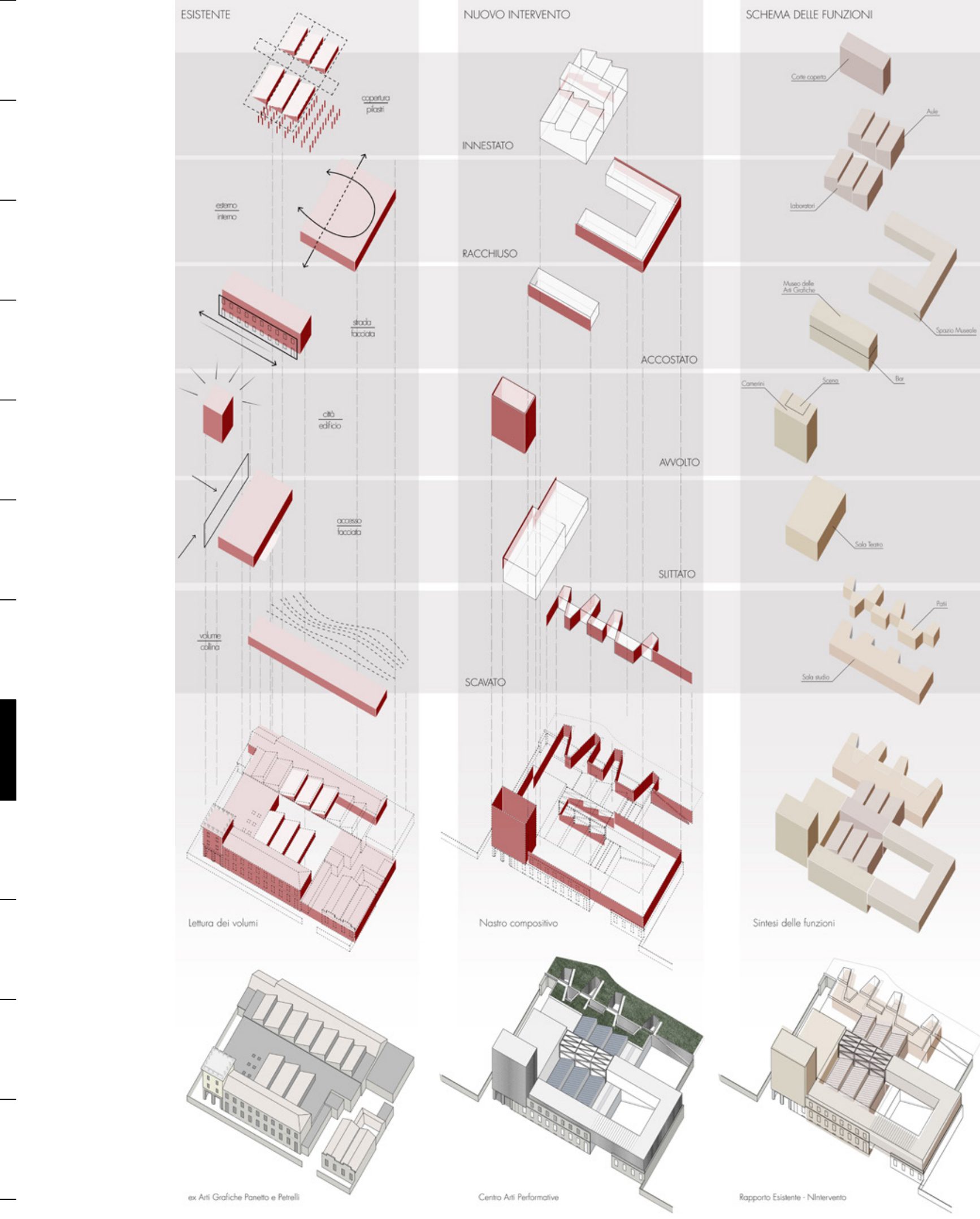


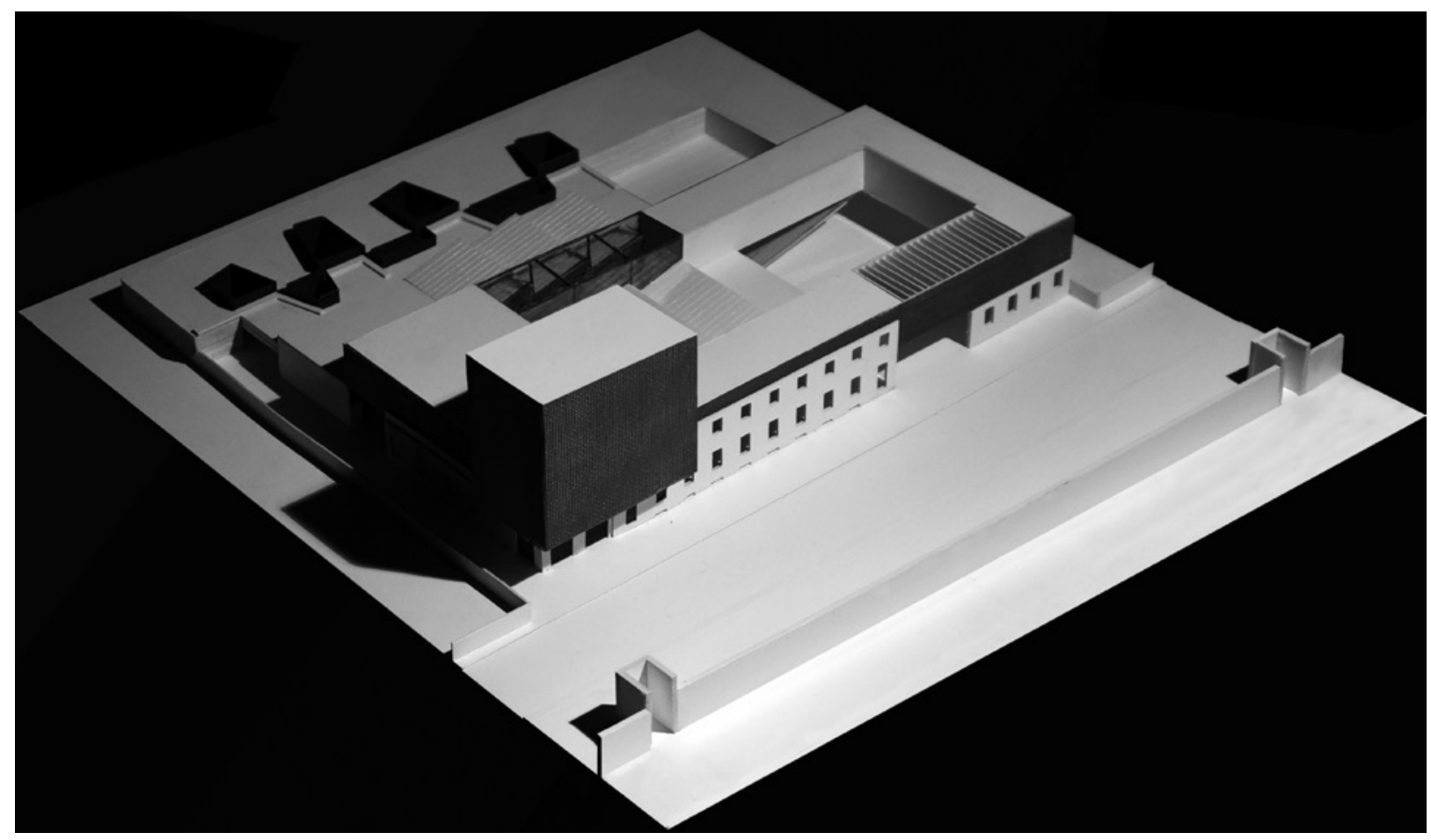

In Spoleto the Performing Arts Centre is the reuse of the Panetto \& Petrelli typography, an important example of industrial architecture that began its activity in the early twentieth century in the Umbrian city with the building construction of a factory located along the walls. The project elaborates the idea of a re-convertible architecture through actions of transformation of the original factory starting from the partial deletion of some additions of the second half of the XX century: with a continuous formal device the project reconfigures the original juxtaposition of the volumes in a plan composition that organizes the new spaces of the building: a perforated metal strip is the element that wraps, grafts, digs and separates the various parts of the factory in the new spaces of a theatre, a museum and laboratories. The original façade as the front of the museum and the custodian's building, whose enlargement becomes the theatre's theatrical tower, in addition to the production spaces of the former printing house, relive in an unique sequence of interlocking spaces between inside and outside the new enclosure of the old factory.

\section{Additions of form}

When the reuse space extends beyond the confines of the building and incorporates the surrounding context, at this point the forms of the architectural project assert themselves as supplementary objects that engage in a dialogue with the existing structure. The two projects create additions of form from the existing structure as
Fig. 11a The reuse of the Panetto\&Petrelli factory in Spoleto, Italy. Design process. Pietro Romitelli, degree thesis Roma, Faculty of Architecture, 2016

Fig. 11b The reuse of the Panetto\&Petrelli factory in Spoleto, Italy. Model. Pietro Romitelli, degree thesis Roma, Faculty of Architecture, 2016 


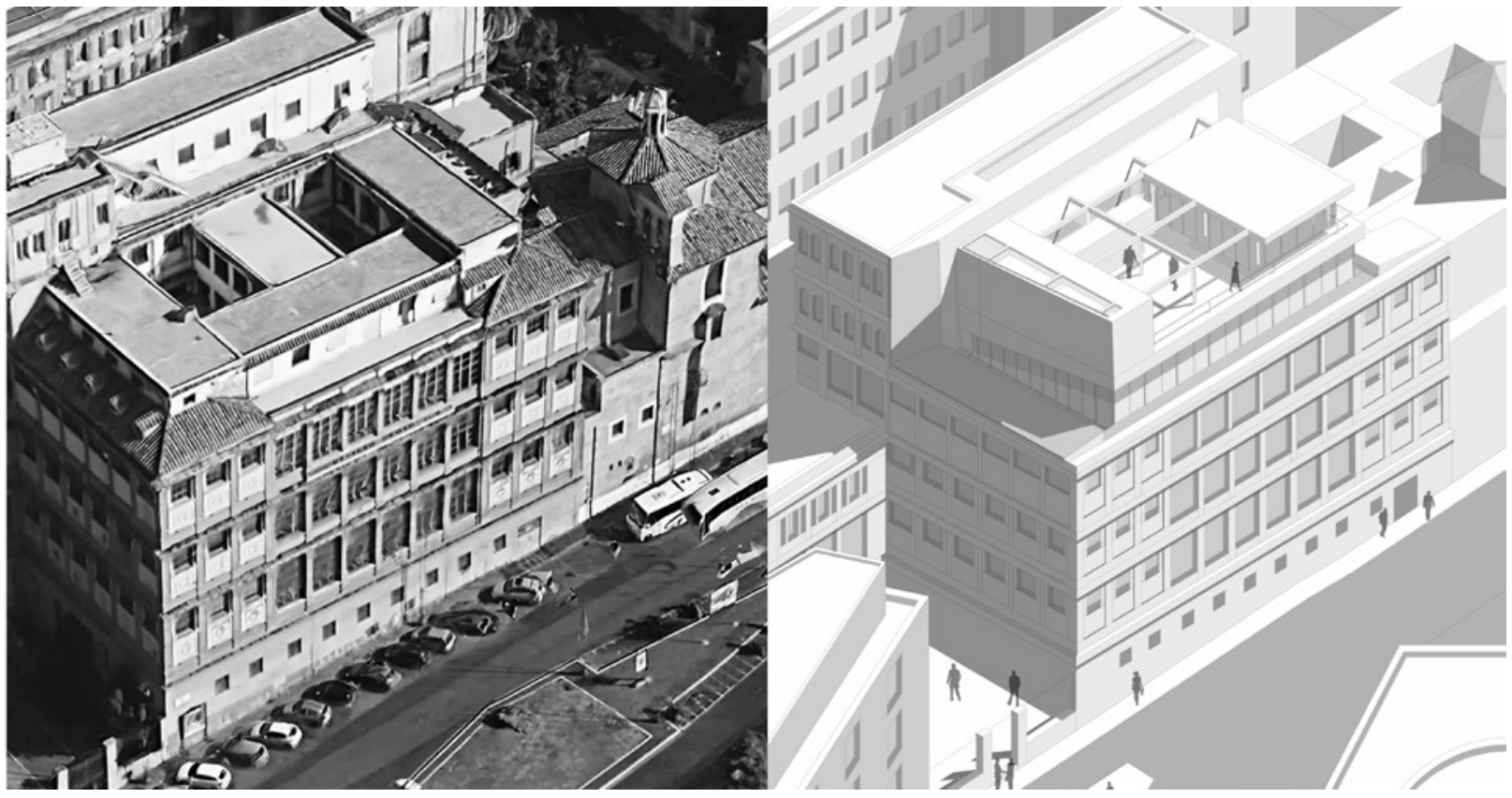

Fig. 12 The reuse of the Geological Institute by R. Canevari in Rome. The top floor new addition. Matteo Dragoni, degree thesis Roma, Faculty of Architecture, 2016 a re-interpretation of the original form, re-submitted in the language and materials of contemporary architecture, a kind of typological enhancement based on the idea of the existent form yet introduced as a new architectural image.

The first is the old Geological Institute, built in Rome in the end of the XIX century; it was settled in the historical city, rising on the foundations of an ancient convent of the Santa Maria della Vittoria church. The design process starts analyzing of the different phases of construction of the urban block, up to the modern building. It was built in a mixed masonry and steel structure. Recently, archaeological excavations have discovered an archaic temple. The building designed by Raffaele Canevari has been completed in several phases and some volumes in excess have altered the top floor. The reuse project redefines the top floor as a new addition of form with a volume, which is inserted additionally in the extant structure creating a new relationship between the different spaces. The original structure and the new one are connected by the same size but they are different because the new order re-interprets the existing in an updated form of language.

The second one is the building complex of the Ministry of Finance, designed in 1955 by Cesare Ligini, in Rome EUR, that consists of three towers and two lower buildings. The project moves from the functional program and the constraints imposed by an international competition that provided for a substantial refurbishment of the interiors without changing the structure and the number of floors. However, it was possible to intervene with a new connection between the buildings. The design process proposes a partial demolition of the base of the original structure, freeing up a new urban space that connects public 
and private spaces. The new functions, offices and hotels are organized in the lower flats of the towers. Here the addition of form is the new connection between the houses, which are located at the top of the three towers. This connection system produces green areas that reduce $\mathrm{CO} 2$ emissions on top of buildings. Furthermore, in this architectural proposal the new double-sided facades contribute to the reduction of energy consumption.

\section{Conclusions}

These teaching experiences explain the challenge of our methodology that aims to make a contribution to defining the discipline of re-use of the existing, proposing a design process to study the formal structure of the abandoned modernist buildings, that are often completely canceled by the progressive autonomy of the individual parts in ruin. And so, the main task that educational experimentation has to face through design is learning from the existing with the aim of creating a language of reuse of the existing in which the architectural figures reinterpret the memory of the lost building, which reappears in a new forms.
Fig. 13a The reuse of the Ministry of Finance, by Cesare Ligini, in Rome EUR. Roberto Amatori, Davide De Santis, degree thesis Roma, Faculty of Architecture, 2015

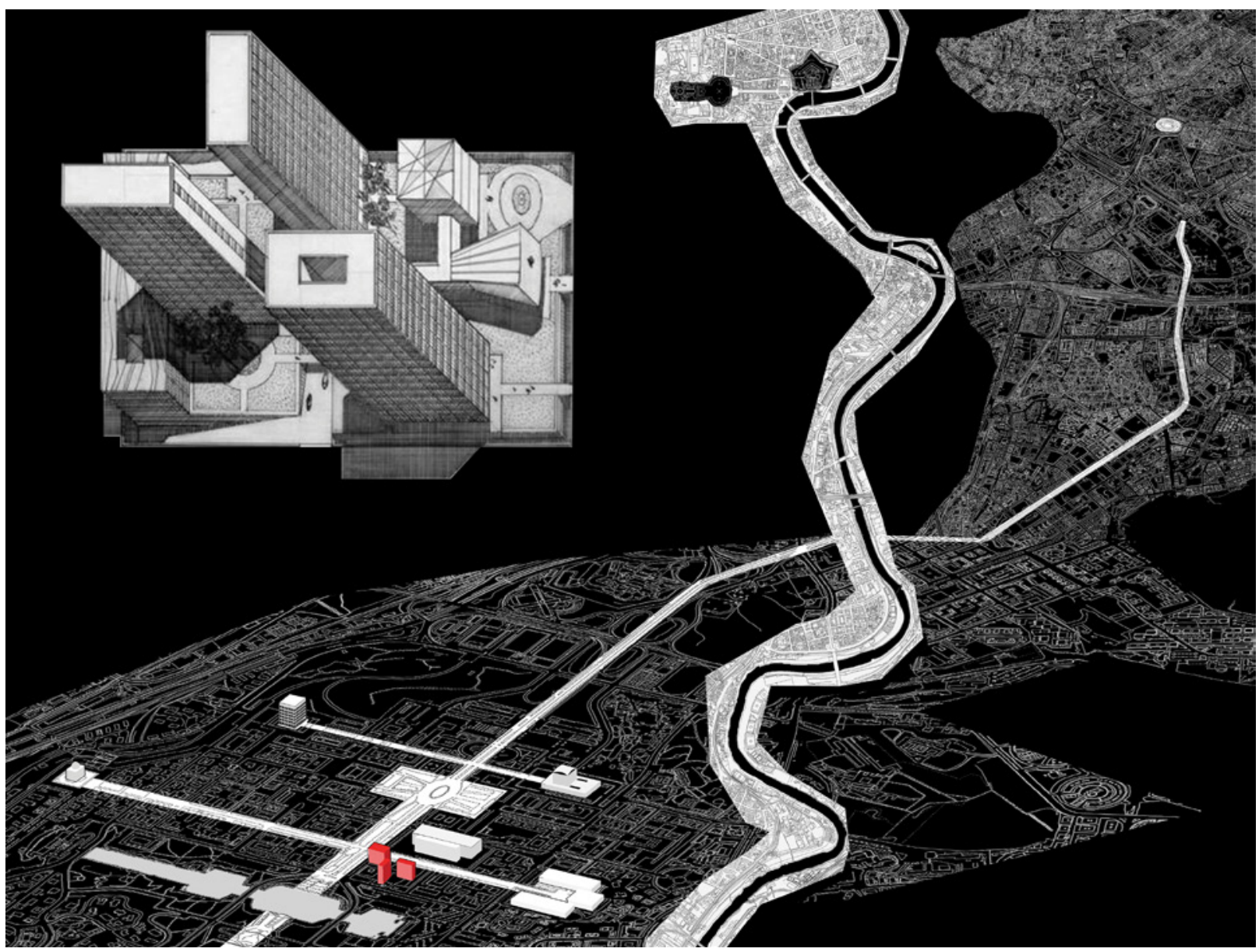



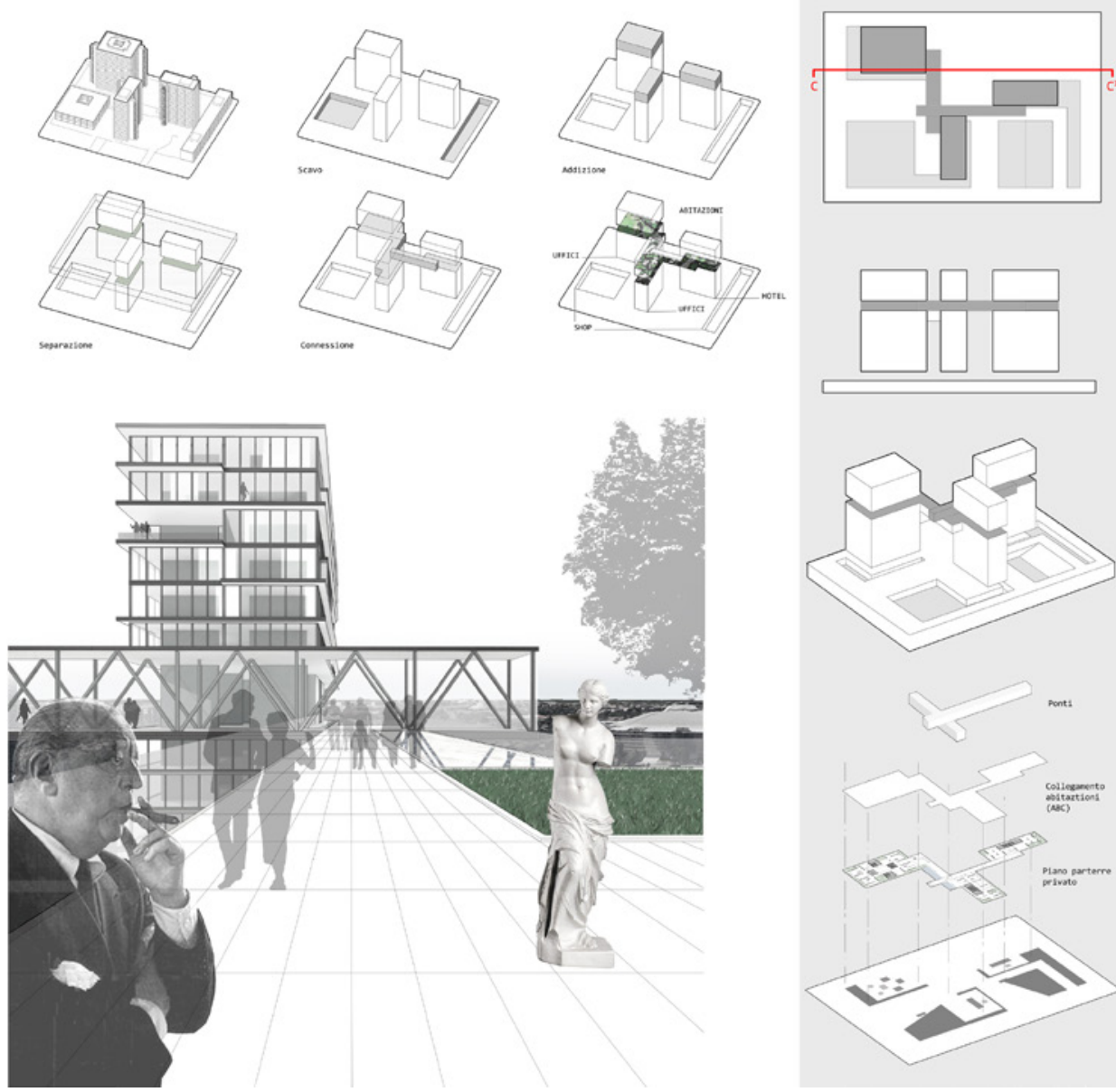

Fig. 13b The reuse of the Ministry of Finance, by Cesare Ligini, in Rome EUR. Model. Roberto Amatori, Davide De Santis, degree thesis Roma, Faculty of Architecture, 2015

Fig. 13c The reuse of the Ministry of Finance, by Cesare Ligini, in Rome EUR. Model. Roberto Amatori, Davide De Santis, degree thesis Roma, Faculty of Architecture, 2015
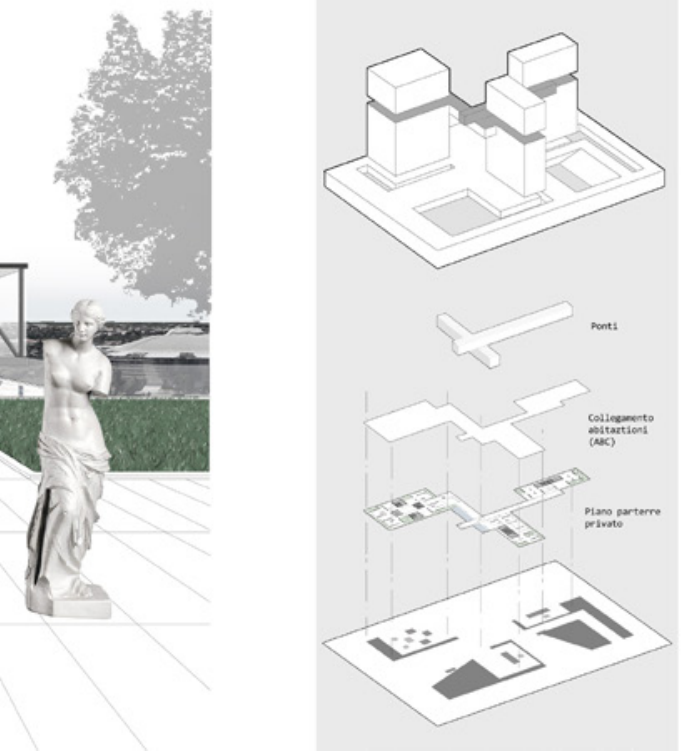

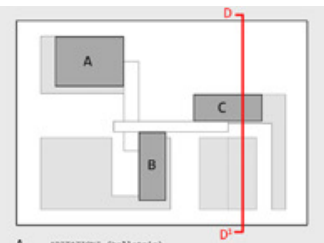

A watration (molinodo)
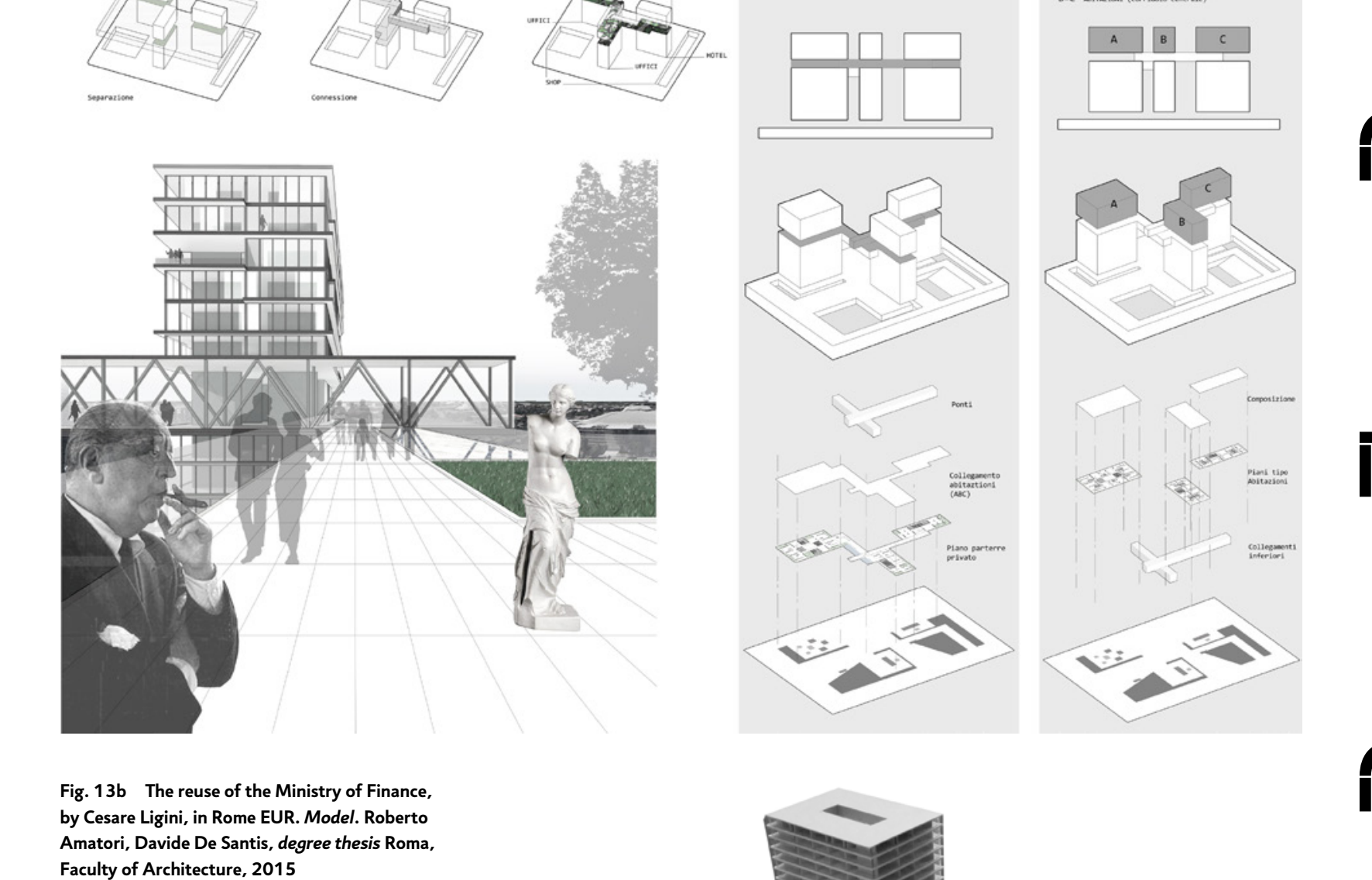

-
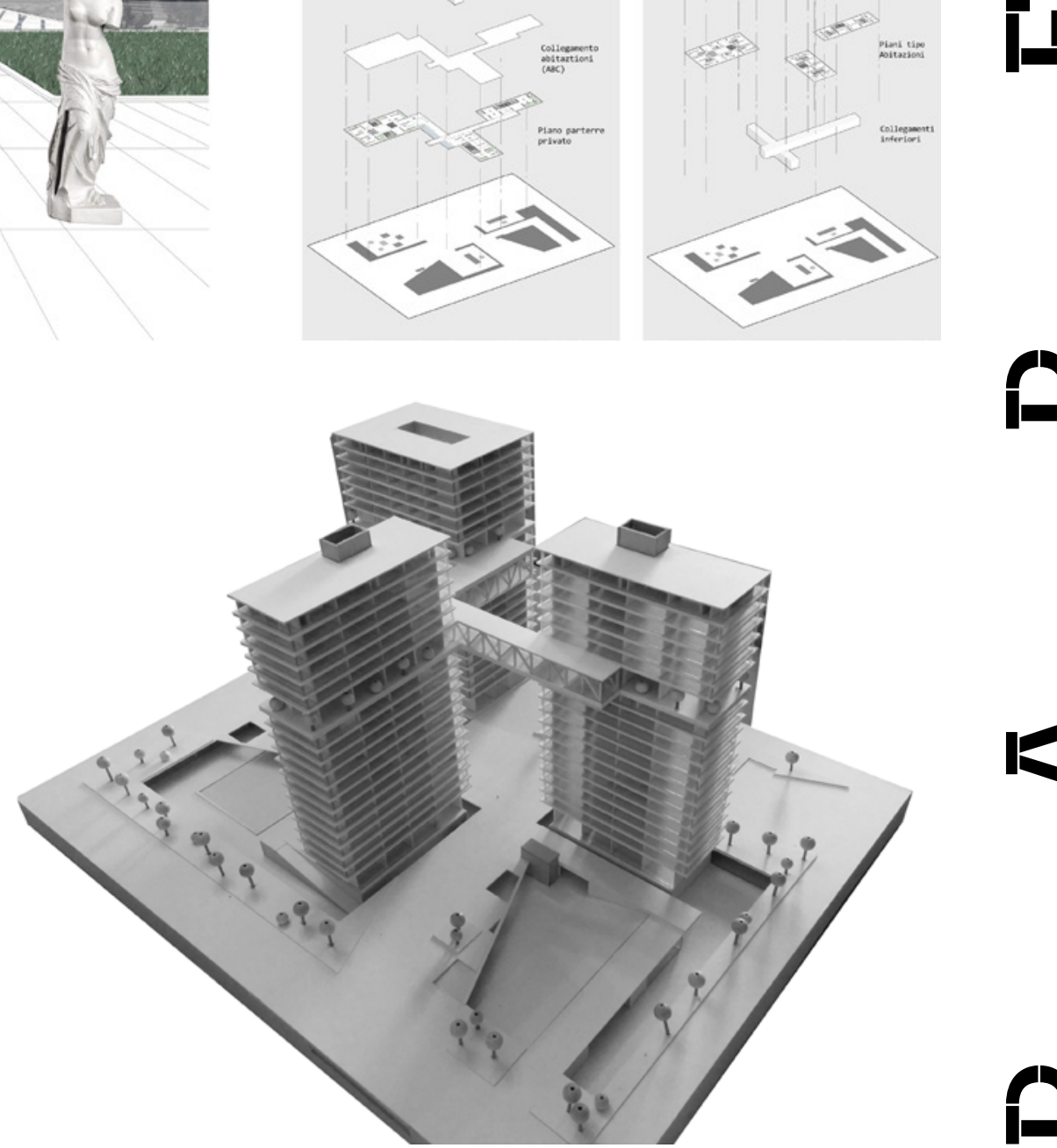
$1 \rightarrow$ The Theatrum Marcelli is a theatre of ancient Rome, still partially preserved, built by the Empereor Augustus in the southern area of Campo Marzio between the Tiber River and the Campidoglio. In the Middle Ages had been used as a place of shops and for the construction of small houses, and in the XIV century it became the property of the Savelli's, a family of merchants that partly restored according to order and on which it took a further construction just to build its own building. In 1500 the Savelli's commissioned Baldassarre Peruzzi who made an architectural addition above the two orders of the ancient theatre. The new plan system adapts itself to the structural spans of the ancient architectural forms

$2 \rightarrow$ The Athenaion temple in Syracuse, built in 570-560 a. C. in the Ortigia island is one of the most significant examples of the architecture of the Greek colonies where, on one hand, the construction according to the archaic style survives and, on the other, the severe and powerful appearance of the composition announces the rule of the growing Doric order, which expresses a particular magnificence in the more peripheral regions of Magna Graecia $3 \rightarrow$ “Et un'altra ve n'è in Vicenza, della quale solamente ho posto $i$ disegni, perché i portichi, ch'èlla hà intorno sono di mia intenzione: e perché non dubito che questa fabbrica non possa esser comparata à gli edificij antichi", “And there is another one in Vicenza, of which I have only placed the drawings, because the porticoes, which are around me, are of my intention: and because I do not doubt that this building can not be compared to the ancient buildings" A. Palladio, I Quattro Libri del'Architettura, Libro Terzo Cap. XX, Venezia, 1570, printed in Milan by U. Hoepli, 1980 $4 \rightarrow$ Gordon Matta-Clark, Gordon Matta-Clark's Building Dissections, typewritten statement by the author, undated (ca. 1970), published in Lotus International, n.133, Milano, 2008 